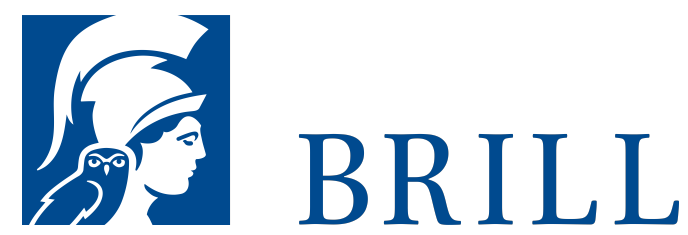

\title{
Concatenatio Catulliana
}

A New Reading of the Carmina

Author: Paul Claes

The arrangement of Catullus' Carmina is one of those controversial issues that in-cite respectable commentators to take up extreme positions. In 1914, the German scholar Bernhard Schmidt described the collection as 'a wild chaos'. Forty-five years later, his compatriot Otto Weinreich riposted with the laconic statement: 'Chaos? Cosmos!' Former attempts to detect a structure in the collection were based on rather subjective assumptions. While translating Catullus' poetry into Dutch, Dr Claes detected an objective foundation: the principle of concatenation, i.e. the recurrence of motifs and phrases in consecutive poems. The generality of this phenomenon proves that the poet conceived of the Carmina as a coherent collection, in which the poems fit like links in a chain. The discovery of this coherence suggests a new reading of Catullus, which has also implications for the constitution of the text.

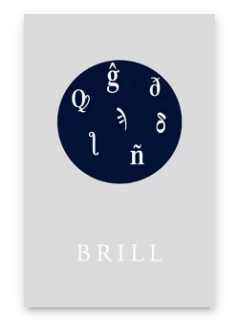

Pages: 173 pp.

Language:

English

Subjects: Greek

\& Latin

Literature,

Classical Studies

Publisher: Brill

Series:

Amsterdam

Studies in

Classical

Philology,

Volume: 9

E-Book (PDF)

Released online:

o1 Oct 2019

ISBN: 978-90-

04-40904-O

List price

USD \$93.00

Hardback

Publication date:

o1 Jan 2002

ISBN: 978-90-

50-63288-1

List price

USD \$93.00 
For more information see brill.com

Order information: Order online at brill.com +44330 333 0049 | customerservices@brill.com Submission information: brill.com/authors

Titles published by Brill | Fink, Brill | mentis or Brill | Schöningh: +49(o)715413279216| brill@brocom.de 